\title{
Dung fungi from Brazil: Agrocybe pediades (Fr.) Fayod (Basidiomycota) in Cerrado
}

Fungos coprófilos do Brasil: Agrocybe pediades (Fr.) Fayod (Basidiomycota) no Cerrado

\author{
F. J. S. Calaça ${ }^{1 *}$; V. G. Cortez ${ }^{2}$; S. Xavier-Santos ${ }^{1}$ \\ ${ }^{1}$ Laboratório de Micologia Básica, Aplicada e Divulgação Científica - FungiLab, Campus Central, Universidade \\ Estadual de Goiás, 75132-903, Anápolis-Goiás, Brazil \\ ${ }^{2}$ Departamento de Biodiversidade, Universidade Federal do Paraná, 85950-000, Palotina-Paraná, Brazil
}

*calacafjs@gmail.com

(Recebido em 27 de fevereiro de 2020; aceito em 05 de junho de 2020)

\begin{abstract}
In the survey of copromycodiversity from Brazil, we present the first records of the genus Agrocybe for the Cerrado biome, represented by the species A. pediades, found on cattle dung in the state of Goiás, central Brazil. We also present detailed morphological descriptions, illustrations, and comments about its distribution and the fimicolous habitat, as well as the cultural characteristics of the specimens.

Keywords: Agaricales, dung-inhabiting fungi, Strophariaceae.

No levantamento da copromicodiversidade brasileira, apresentamos os primeiros registros do gênero Agrocybe para o bioma Cerrado, representado pela espécie A. pediades, encontrada sobre esterco bovino no estado de Goiás, Brasil. Apresentamos descrições morfológicas, ilustrações e comentários detalhados sobre sua distribuição e hábito fimícola, bem como as características dos espécimes em meio de cultura.

Palavras-chave:Agaricales, fungos de esterco, Strophariaceae.
\end{abstract}

\section{INTRODUCTION}

Dung fungi, also described as coprophilous or fimicolous fungi in accordance with the choice of substrates [1], are an artificial group encompassing the fungi with physiological and ecological adaptations, at different levels, to grow on the dung of a diverse animals assembles, mainly herbivores. In Brazil, there are few studies reporting species of dung fungi and, until 2017, the fungal diversity of this group accounted with 225 species [2]. Among the representatives of agaricoid dung fungi, a few species were recorded in Brazil, mostly in the genera Coprinellus $\mathrm{P}$. Karst., Coprinopsis P. Karst., Deconica (W.G. Sm.) P. Karst., Panaeolus (Fr.) Quél. and Psilocybe (Fr.) P. Kumm. [3].

Agrocybe Fayod is a mushrooms genus belonging to the family Strophariaceae (Basidiomycota: Agaricales), comprising about 100 described species [4, 5]. The genus has wide distribution, occurring in natural (forests, on plant debris and soil, sand dunes) or anthropic (gardens, manured soil) areas, being considered as a poorly selective genus in substrate choice $[6,7,8]$. The fimicolous species of Agrocybe, which grows on dung or heavily manured soils, are poorly recorded, since they are a few species and because they do not develop on moist chambers, as observed in other dung fungi species [9].

Nine species of Agrocybe were recorded in dung or manured soil worldwide: A. allocystis Singer, A. amara (Murrill) Singer, A. coprophila (Rick) Singer, A. fimicola (Speg.) Singer, A. hortensis (Burt) Singer, A. perfecta (Rick) Singer, A. platensis (Speg.) Singer, A. procera Singer, and A. stercoraria Pegler [1, 9, 10]. According to Coimbra (2015) [11], 21 species of Agrocybe occur in Brazil and only four are considered fimicolous: A. allocystis, A. fimicola (Speg.) Singer, A. neocoprophila Singer, and A. subpediades (Murrill) Watling. However, until now there were no records of this genus for Brazilian Cerrado. Herein, we present the first occurrence of both, the genus Agrocybe and the species A. pediades for the biome, contributing to the increase in the knowledge of the mycobiota from Cerrado. 


\section{MATERIAL AND METHODS}

We found the basidiomes of an Agrocybe species, growing on cattle dung (Bos taurus L.) in an organic vegetable garden in the municipality of Anápolis, Goiás state, Brazil (16 ${ }^{\circ} 16^{\prime} 27.26 " \mathrm{~S}$, $\left.48^{\circ} 54^{\prime} 27.13 \mathrm{WW}\right)$. The basidiomes were photographed, collected with part of the substrate, packaged in paper boxes, and taken to the laboratory. Macroscopic features were described from fresh basidiomes. Color names and codes used in the macroscopic descriptions were based on Kornerup and Wanscher (1978) [12]. The remaining specimens were dried in a drying oven at about $40^{\circ} \mathrm{C}$ for one week. Microscopic structures were observed from freehand cuts of dried material using a razor blade. The sections were rehydrated in $3 \% \mathrm{KOH}$ and dyed with floxine or Melzer's reagent, when necessary. The microscopic structures were photographed at $\times 1000$ magnification by using an Olympus CX31 optical microscope and a digital camera. Measurements were taken by using the software Piximètre, v. 5.9 R 1532 [13], where for basidiospores measurements, Q refers to the quotient between the length and width, $Q m$ is the medium value of $Q$, and $n$ is the number of measured spores. Voucher material was preserved and deposited at HUEG Herbarium [14].

Pure cultures of $A$. pediades was obtained inoculating a spore suspension on potato dextrose agar culture medium (PDA, $3.9 \mathrm{~g}$ in $100 \mathrm{~mL}$ of water) with the addition of $0.25 \mathrm{mg} / \mathrm{mL}$ of chloramphenicol in plate Petri dish and incubated in BOD at $26^{\circ} \mathrm{C}$. Macro morphological aspects of culture were described according to Olmos-Fuertes and Herrera (1973) [15]. For microscopical description, fragments of mycelium were mounted on slides, with the aid of lactophenol cotton blue staining, photographed and measured with the same methodology adopted to microscopical descriptions of the basidiomes.

\section{RESULTS AND DISCUSSION}

Agrocybe pediades (Fr.) Fayod, Annales des Sciences Naturelles Botanique 9: 358 (1889) 三Agaricus pediades Fr., Systema Mycologicum 1: 290 (1821)

Figures 1-2.

Macroscopic features: Pileus 10-20 mm diam., hemispheric to convex, yellowish grey to greyish beige in wet condition (4B2, 4C2), surface smooth to slightly rugulose, with a uniform margin, no veil remnants observed. Lamellae yellowish white to yellowish grey (4A2, 4B2), crowded, slightly wavy, entire edge, adnate; lamellulae present. Stipe pale yellow to greyish yellow (4A3, 4B3), central, fibrous in consistency, cylindrical, sometimes slightly bulbous at the base and partially squamulose; annulus absent; context $2-3.5 \mathrm{~mm}$, fibrous to slightly fleshy when fresh, yellowish white (4A2); spore-print dark brown (7F4, 7F5).

Microscopic features: Basidiospores (10.3) 11.2 - $12.8(14) \times(6.3) 6.9-8.2$ (8.7) $\mu \mathrm{m},(Q=1.5$ -1.7 (1.8), $Q m=1.6, n=50$ ), smooth, broadly ellipsoid in face view and ellipsoid in side view, thick-walled up to $1.1-1.3 \mu \mathrm{m}$, with a $1.3-1.5 \mu \mathrm{m}$ wide germ pore, light-brown (7D6) under light microscope. Basidia $25-30 \times 9.4-13 \mu \mathrm{m}$, clavate, mixed two and 4-spored. Pleurocystidia absent. Cheilocystidia $20-30 \times 8.7-13.5 \mu \mathrm{m}$, abundant, crowded, irregularly lageniform to narrowly utriform with subcapitate to capitate apex $2.5 \mu \mathrm{m}$ average width, hyaline and thin-walled. Pileipellis hymeniform, composed by clavate, hyaline, thin to slightly thickened-walled elements, (12.5) 14.51 $-19.77(19.8) \times 6.7-11.59(11.6) \mu \mathrm{m}$. Stipitipellis is a dry and regular cutis of rarely branched, 5 $-7 \mu \mathrm{m}$ wide hyphae with cylindrical elements, clamp-connections present.

Cultures in Potato Dextrose Agar medium (PDA): after 14 days at $26^{\circ} \mathrm{C}$ somewhat restricted, with slow growing, attaining $7-8 \mathrm{~cm}$ in four weeks. Surface downy, white (1A1), not becoming zonate with time; reverse uncolored. Hyphae system monomitic, hyphae hyaline $2-2.5 \mu \mathrm{m}$ diameter, few clamp connections observed (Figure 1, G-I).

Known distribution - widespread in subtropical and temperate regions.

Material examined - Brazil, Goiás, Anápolis, Vale das Antas farms sector, rural zone of municipality Anápolis, $16^{\circ} 16^{\prime} 27.26^{\prime \prime S} 48^{\circ} 54^{\prime} 27.13^{\prime \prime} \mathrm{W}$, found growing directly on cattle dung (Bos taurus L.) in an organic vegetable garden, 21 Nov 2018, F. J. S. Calaça FJSC86 (HUEG: 12037).

Notes - This is the first record of the genus Agrocybe in Brazilian Cerrado, with the occurrence of $A$. pediades in this domain. The species was observed occurring in a fimicolous substrate (cattle 
dung), increasing the records of coprophilous/fimicolous basidiomycetes that occur in Brazil Central to four species [16]. Before that, the validated records of this species were only for the Southern Region of Brazil, with the predominance of the Pampa and Atlantic Forest biomes [11, $16]$.
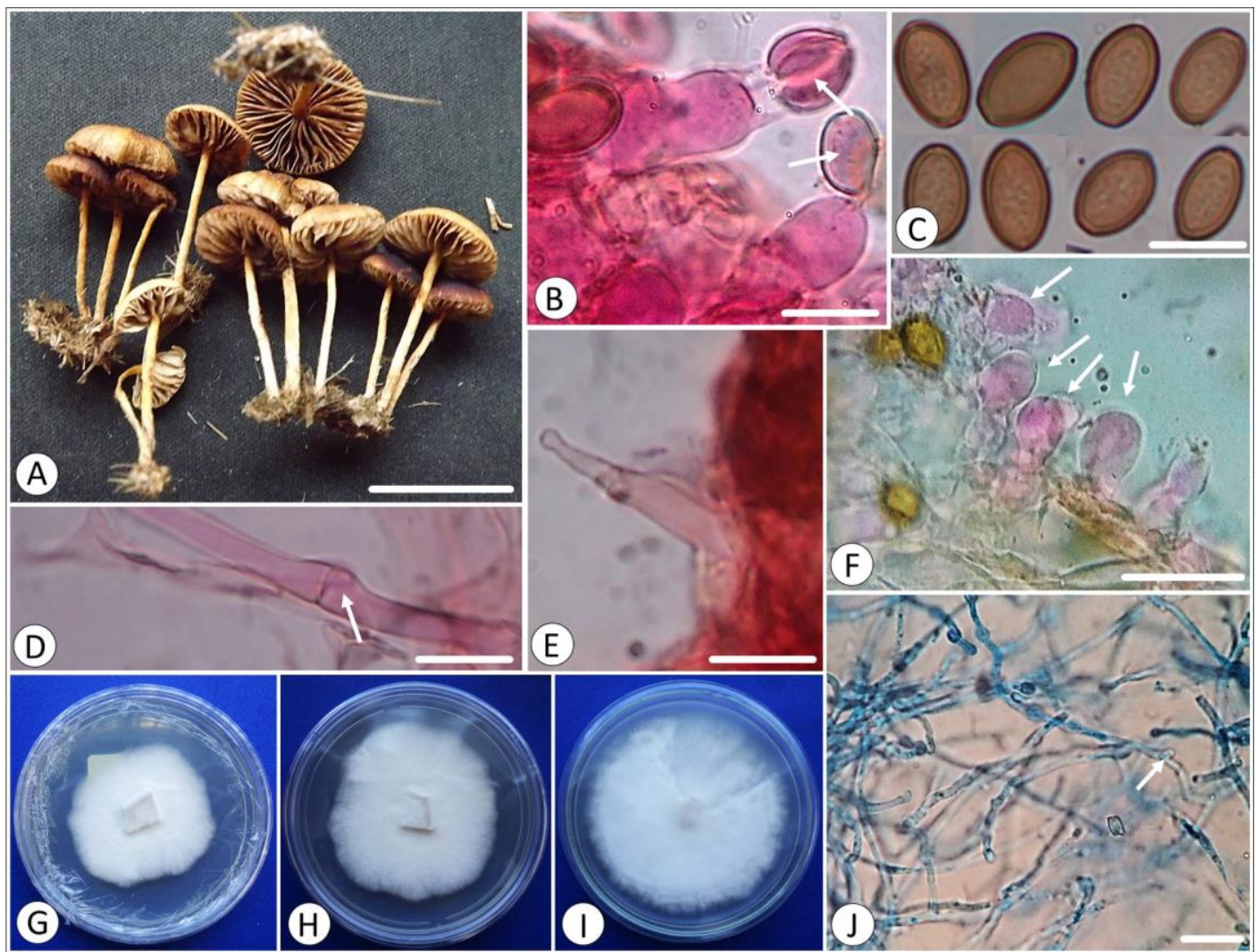

Figure 1: Agrocybe pediades. (A) Basidiomes. (B) Two and four-sterigmate basidia with young spores in formation (arrows, dyed with floxine). (C) Basidiospores (not stained). (D) Clamp-connection (arrow). (E) Irregularly lageniform to narrowly utriform cheilocystidia. $(F)$ Clavate elements of pileipellis (arrows). $(G)$

Two weeks of A. pediades culture in PDA medium. (H) Three weeks culture in PDA medium. (I) Four weeks culture in PDA medium, with 7-8 cm $(\emptyset)$. (J) Monomitic hyphae system from culture in PDA medium, dyed with lactophenol cotton blue. Scale bars $(A)=2 \mathrm{~cm},(B-F)=10 \mu \mathrm{m},(\mathrm{J})=20 \mu \mathrm{m}$. 


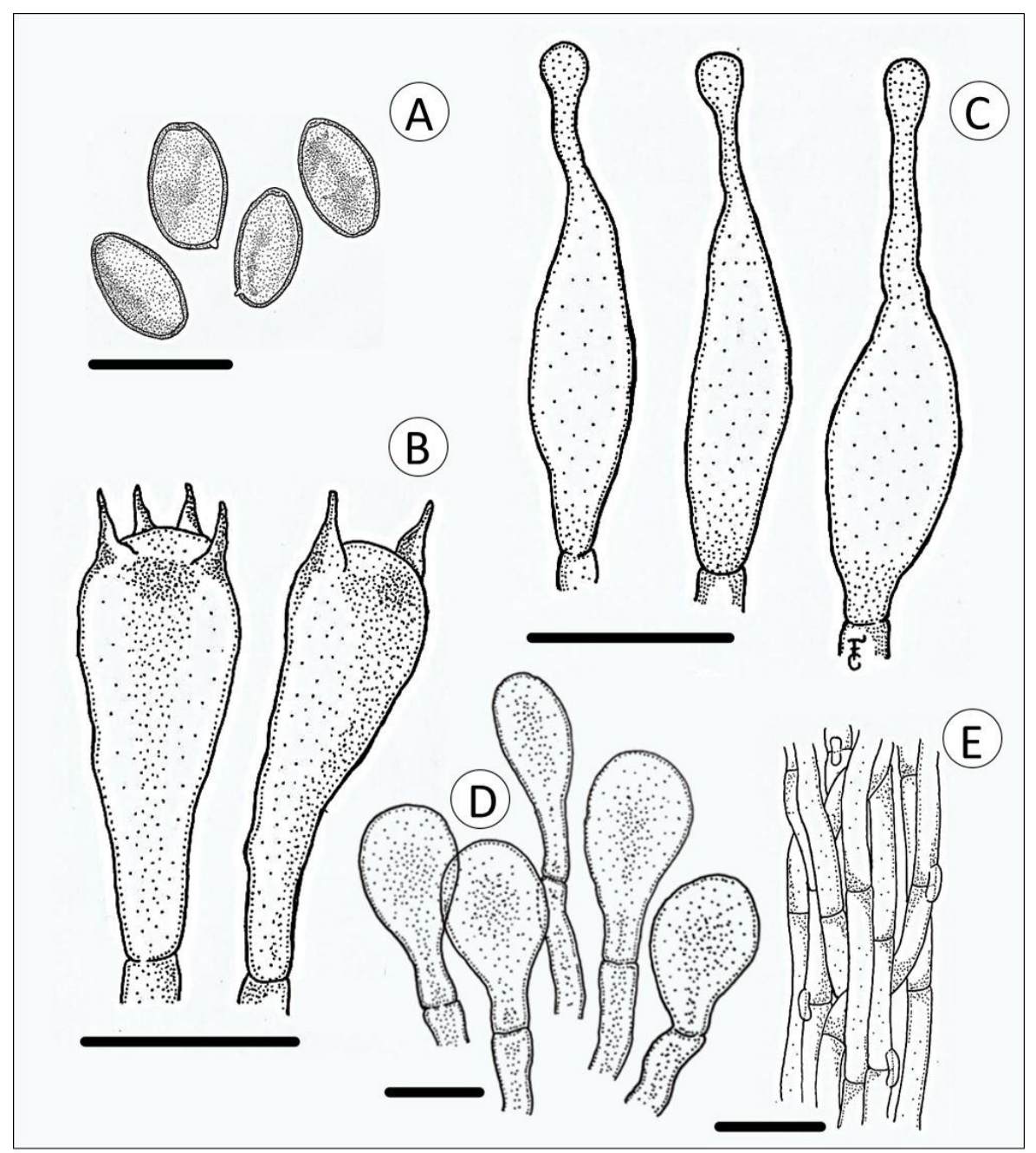

Figure 2: Microscopic features line drawings of Agrocybe pediades. (A) Basidiospores. (B) Four and twosterigmate basidia. (C) Cheilocystidia. (D) Pileipellis elements. (E) Stipitipellis. Scale bars $10 \mu \mathrm{m}$.

Some close related species, as Agrocybe cubensis (Murrill) Singer and A. fimicola (Speg.) Singer differ from our material by macro or microscopic characteristics and substrate choice. Agrocybe cubensis grows on dead vegetable residues, presents an appendiculate veil and 4-spored basidia [6]. This species was found in Brazil, in the state of Paraná [17]. Agrocybe fimicola was established as a variety of $A$. pediades by Nauta $(2004,2005)[6,18]$, who considered this species within a complex of three varieties (A. pediades var. fimicola, A. pediades var. pediades and A. pediades var. cinctula), macroscopically distinguishable by the presence or absence of conspicuous appendiculate veil, annulus, and occurrence or not in dung. Meijer (2008) [19] collected and described specimens of A. fimicola from state of Paraná, Brazil, found growing on pasture in dung of horse and buffalo. Currently, A. fimicola remains an independent species and A. pediades var. fimicola is yet considered its synonymy [8, 18, 20,21].

Table 1 shows the distribution of Agrocybe species with fimicolous habit recorded in Brazil, all from the South Region of the country. Thus, our data adds the first record of this genus outside a region with predominance of subtropical climate $\mathrm{Cfa}$ and/or $\mathrm{Cfb}$, according to Köppen-Geiger classification [22], occurring in a region of seasonal tropical climate (Aw type), with well-defined dry and rainy season (Brazilian savanna). This record expands the geographical distribution of this genus, which probably is very widespread in Brazil, including its occurrence as dung-inhabiting genus. 
Table 1: Agrocybe species with fimicolous habit (occurring on dung or highly manured soil), reported from Brazil in accordance with the literature.

\begin{tabular}{|c|c|c|c|}
\hline Species & $\begin{array}{c}\text { Fimicolous substrate } \\
\text { types }\end{array}$ & $\begin{array}{c}\text { Brazilian } \\
\text { state }\end{array}$ & Key references \\
\hline A. allocystis & on dung or soil & PR & $\begin{array}{c}\text { Singer (1969) [23], Coimbra } \\
\text { (2015) [11] }\end{array}$ \\
\hline A. fimicola & $\begin{array}{l}\text { on dung (cow, buffalo, } \\
\text { horse), soil with grass, or as } \\
\text { saprotrophic (plant debris) }\end{array}$ & PR, RS & $\begin{array}{l}\text { Meijer }(2006,2008)[24,19], \\
\text { Coimbra }(2015)[11]\end{array}$ \\
\hline A. neocoprophila & on dung or soil & RS & $\begin{array}{c}\text { Singer (1965) [25], Coimbra } \\
\text { (2015) [11] }\end{array}$ \\
\hline A. subpediades & on dung & PR & $\begin{array}{c}\text { Watling (1992) [17], Meijer } \\
\text { (2006) [24], Coimbra (2015) } \\
{[11]}\end{array}$ \\
\hline A. pediades & $\begin{array}{c}\text { on manured soil with cattle } \\
\text { dung }\end{array}$ & GO & Calaça et al. (present study) \\
\hline
\end{tabular}

The fungal diversity of Cerrado, it is still underexplored, with the most recent survey including about over 640 species confirmed, mostly phytopathogenic fungi [26, 27]. The biome is composed by a phytophysiognomic mosaic along a topographic gradient that allows the existence of a gradient of vegetation, allowing formations that vary between grasslands, savannas and forests formations [28]. Due to its biological diversity, high degrees of endemism, rapid habitat loss and land-use changes, the Cerrado is classified as a global biodiversity hotspot $[29,30]$. Whereas much of the unknown fungal biodiversity may be in underexploited geographical areas or habitats, like biodiversity hotspots [31], efforts to survey the fungi of the Cerrado should be encouraged, aiming the search for new species.

These efforts should be directed mainly to those species considered as cryptic or that develop mostly on substrates little explored by mycologists, as dung for example. Unfortunately, the study of dung fungi in Brazil lacks human resources in quantity and quality to explore more of diversity of these fungi in the country. The estimated diversity for the group, as we have shown in previous data $[2,16]$, tends to increase considerably by including unexplored areas of the country (i.e. almost total Brazilian territory in regards to this fungal group) as well as the study of new substrates, especially from native hosts.

\section{CONCLUSION}

We presented here the first record of the occurrence of the agaricoid mushroom genus Agrocybe, with the record of $A$. pediades occurring in a fimicolous environment in the Brazilian Cerrado biome, contributing with new data on the biology and ecology of dung-inhabiting fungi from Brazil. Furthermore, we reinforce the need for additional studies in different locations and substrates that favor the occurrence of dung-inhabiting fungi, especially in threatened biomes, such as the Brazilian Cerrado, with the purpose of surveying the richness of this group of organisms that are still little studied in the Cerrado, which may contribute to reinforcing the need to preserve it.

\section{ACKNOWLEDGEMENTS}

This work was financed by the Fundação de Amparo à Pesquisa do Estado de Goiás (FAPEG, process $n^{\circ}$. 201810267000595). We thank the reviewers for their insightful comments and efforts towards improving the final version of the manuscript.

\section{REFERENCES}

1. Doveri F. Fungi Fimicoli Italici. Trento: A.M.B: Fondazione Studi Micologici; 2004. 1104 p. 
2. Calaça FJS, Araújo JC, Xavier-Santos S. O status ecológico das comunidades de fungos coprófilos. Pesq Ensino Ci Exatas Nat. 2017;1(2):136-143, doi: 10.29215/pecen.v1i2.452

3. Melo RFR, Chikowski RS, Miller AN, Maia LC. Coprophilous Agaricales (Agaricomycetes, Basidiomycota) from Brazil. Phytotaxa 2016;266(1):001-014, doi: 10.11646/phytotaxa.266.1.1

4. Kirk PM, Cannon PF, Minter DW, Stalpers JA. Dictionary of the Fungi. Wallingford: CABI; 2008. 771p.

5. Matheny PB, Moreau P-A, Vizzini A, Harrower E, de Haan A, Contu M, Curti M. Crassisporium and Romagnesiella, two new genera of dark-spored Agaricales. Syst Biodivers. 2015;13:28-41, doi: 10.1080/14772000.2014.967823

6. Nauta MM. Agrocybe Fayod. In: Noordeloos ME, Kuyper TW, Vellinga EC, editors. Flora Agaricina Neerlandica: Critical monographs on families of agarics and bolete occurring in the Netherlands. Boca Raton: Taylor \& Francis; 2005. 204-221p.

7. Kuo M. 2006. The genus Agrocybe. Available at: http://www.mushroomexpert.com/agrocybe.html. Accessed 13 June 2019.

8. Niveiro N, Uhart M, Albertó E. Revision of the genera Agrocybe and Cyclocybe (Strophariaceae, Agaricales, Basidiomycota) in Argentina. Rodriguésia. 2020;71:1-26, doi: 10.1590/21757860202071038

9. Doveri F. Occurrence of coprophilous Agaricales in Italy, new records, and comparisons with their European and extra european distribution. Mycosphere. 2010;1:103-140.

10. Singer R. Keys for the identification of the species of Agaricales I. Sydowia. 1977;30:192-279.

11. Coimbra VRM. Checklist of Central and South American Agaricales (Basidiomycota) II: Strophariaceae. Mycosphere 2015;6:441-458, doi: 10.5943/mycosphere/6/4/6

12. Kornerup A, Wansher JH. Methuen Handbook of Colour. London: Eyre Methuen; 1978. 32p.

13. Henriot A, Cheype JL. 2017. Piximètre, la measure des dimensions sur images. Available at: http://www.piximetre.fr/. Accessed 13 June 2019.

14. Thiers B (continuously updated) Index Herbariorum: a global directory of public herbaria and associated staff. New York Botanical Garden's Virtual Herbarium. Available at: http://sweetgum.nybg.org/ih/. Accessed 04 May 2020.

15. Olmos-Fuertes C, Herrera T. Comportamiento de micelios de los generos Agrocybe, Panus y Psilocybe (Agaricales) en diferentes medios de cultivo. Bol Soc Mex Micol. 1973;7:151-159.

16. Calaça FJS, Silva NC, Xavier-Santos S. A checklist of coprophilous fungi and other fungi recorded on dung from Brazil. Mycotaxon. 2014;128(1):1-22, doi: 10.5248/128.205

17. Watling R. Observations on the Bolbitiaceae - 30. Some Brazilian taxa. Bol Soc Argent Bot. 1992;28: 77-103.

18. Nauta MM. Notulae ad floram agaricinam neerlandicam - XLIII. Notes on Agrocybe. Persoonia 2004; 18:429-433.

19. Meijer AAR. Macrofungos notáveis das florestas de pinheiro-do-paraná. Colombo, Paraná: Embrapa Florestas; 2008. 431 p.

20. IFP. Index Fungorum Partnership. 2019. Agrocybe fimicola (Speg.) Singer 1952. Available at: http://www.speciesfungorum.org/Names/SynSpecies.asp?RecordID=292334. Accessed 13 June 2019.

21. MycoBank Database - Fungal Databases, Nomenclature \& Species Banks. 2019. Agrocybe fimicola. Available at: http://www.mycobank.org/BioloMICSDetails.aspx?Rec=220942. Accessed 13 June 2019.

22. Peel MC, Finlayson BL, McMahon TA. Updated world map of the Köppen-Geiger climate classification. Hydrol Earth Syst Sc. 2007;11:1633-1644, doi: 10.5194/hess-11-1633-2007

23. Singer R. Mycoflora australis. Nova Hedwigia1969;29: 1-405.

24. Meijer AAR. Preliminary list of the Macromycetes from the Brazilian state of Paraná. Bol Mus Bot Mun. 2006;68:1-55.

25. Singer R. Interesting and new Agaricales from Brazil. Atlas do IMUR. 1965;2:15-59.

26. Maia LC, Carvalho-Jr. AA, Cavalcanti LH, et al. Diversity of Brazilian fungi. Rodriguésia. 2015;66:10331045, doi: 10.1590/2175-7860201566407

27. Maia LC, Carvalho-Jr. AA, editors. Fungos. In: Catálogo de plantas e fungos do Brasil [online]. $1^{\text {st }}$ vol. $2^{\text {nd }}$ ed. Rio de Janeiro: Andrea Jakobsson Estúdio: Instituto de Pesquisa Jardim Botânico do Rio de Janeiro; 2010. p. 93-261.

28. Ribeiro JF, Walter BMT. As principais fitofisionomias do bioma Cerrado, In: Sano SM, Almeida SP, Ribeiro JF, editors. Cerrado: ecologia e flora. Brasília: Embrapa; 2008. p. 151-212.

29. Myers N, Mittermeier RA, Mittermeier CG, Fonseca GAB, Kent J. Biodiversity hotspots for conservation priorities. Nature. 2000;403:853-858, doi: 10.1038/35002501

30. Strassburg BBN, Brooks T, Feltran-Barbieri R, et al. Moment of truth fir the Cerrado hotspot. Nat Ecol Evol. 2017;1:0099, doi: 10.1038/s41559-017-0099

31. Hawksworth DL, Lücking R. Fungal diversity revisited: 2.2 to 3.8 million species. Microbiol Spectr. 2017;5:FUNK-0052, doi: 10.1128/9781555819583.ch4 